\title{
PROFIL PROTEIN DAN ASAM AMINO KEONG IPONG-IPONG (Fasciolaria salmo) PADA PENGOLAHAN YANG BERBEDA
}

\section{(Protein and Amino Acid Profiles in Ipong-ipong Snail [Fasciolaria salmo] on Different Processing)}

\author{
Sri Purwaningsih ${ }^{1 *}$, Ella Salamah", dan Gian P Apriyana ${ }^{1}$ \\ 'Departemen Teknologi Hasil Perairan, Fakultas Perikanan dan Ilmu Kelautan (FPIK), \\ Institut Pertanian Bogor, Bogor 16680
}

\begin{abstract}
Ipong-Ipong (Fasciolaria salmo) snail is a mollusk from marine gastropod class in Cirebon, West Java which is consumed by public and believed to improve health, but no research on the protein and amino acid content. This study aimed to determine the proximate content, acid insoluble ash, amino acids (before and after treatment), and content of taurine on the best methods. The research was conducted in two parts. The first part covers sampling, identification, preparation, determination of size and weight, calculation of body recovery, processing, and organoleptic tests. The second part consists of processing treatments boiling $\left(100^{\circ} \mathrm{C}\right.$ for 15 minutes), steaming $\left(100^{\circ} \mathrm{C}\right.$ for 20 minutes), and boiling with the addition of $3 \%$ salt for 15 minutes. The results showed that the treatment gives a significant effect in fat, protein, water, ash and acid insoluble ash content ( $a=0.05$ ). The highest content of essential amino acids in Ipong-ipong snail was arginine and non-essential amino acid was glutamic. The treatment method causes decreased in amino acid content. Steaming resulted in a decrease of taurine content of $164.17 \mathrm{mg} / 100 \mathrm{~g}$ to $149.62 \mathrm{mg} / 100 \mathrm{~g}$.
\end{abstract}

Keywords: amino acids, Fasciolaria salmo, protein, taurine

\begin{abstract}
ABSTRAK
Keong Ipong-ipong (Fasciolaria salmo) merupakan moluska dari kelas gastropoda laut di Cirebon, Jawa Barat yang dikonsumsi oleh masyarakat dan diyakini dapat meningkatkan kesehatan, namun belum pernah ada penelitian mengenai kandungan protein dan asam aminonya. Penelitian ini bertujuan untuk menentukan kandungan proksimat, abu tak larut asam, asam amino (sebelum dan setelah pengolahan), serta kandungan taurin pada metode terbaik. Penelitian ini dilakukan dalam dua bagian. Bagian pertama meliputi pengambilan sampel, identifikasi, preparasi, penentuan ukuran dan bobot, perhitungan rendemen tubuh, pengolahan, dan uji organoleptik. Bagian kedua meliputi perlakuan pengolahan terdiri dari perebusan $\left(100^{\circ} \mathrm{C}\right.$ selama 15 menit), pengukusan $\left(100^{\circ} \mathrm{C}\right.$ selama 20 menit), dan perebusan dengan penambahan $3 \%$ garam selama 15 menit. Hasil penelitian menunjukkan bahwa pengolahan memberikan pengaruh nyata pada kandungan lemak, protein, air, abu, dan abu tak larut asam $(\alpha=0.05)$. Kandungan asam amino esensial tertinggi pada keong ipong-ipong adalah arginin dan asam amino non esensial tertinggi adalah asam glutamat. Metode pengolahan (rebus, kukus, dan kukus menggunakan 3\% $\mathrm{NaCl}$ ) menyebabkan penurunan kandungan asam amino. Pengukusan mengakibatkan penurunan kandungan taurin dari $164.17 \mathrm{mg} / 100 \mathrm{~g}$ menjadi $149.62 \mathrm{mg} / 100 \mathrm{~g}$.
\end{abstract}

Kata kunci: asam amino, Fasciolaria salmo, protein, taurin

"Korespondensi: Departemen Gizi Masyarakat, Fakultas Ekologi Manusia (FEMA), Institut Pertanian Bogor, Bogor 16680. Email: sripurwa65@yahoo.com; sripurwa65@gmail.com 


\section{PENDAHULUAN}

Kandungan zat gizi makro dalam bahan pangan terdiri atas karbohidrat, lemak, dan protein, sedangkan gizi mikro terdiri dari vitamin dan mineral. Protein sebagai salah satu zat gizi makro memiliki fungsi di dalam tubuh yaitu untuk membentuk jaringan baru dan mempertahankan jaringan yang telah ada. Protein tersusun atas dua puluh asam amino yang berbeda. Tubuh manusia tidak dapat mensintesis sembilan asam amino diantaranya isoleusin, leusin, lisin, methionin, fenilalanin, threonin, triptofan, valin, dan histidin. Asam amino tersebut dikenal sebagai asam amino esensial yang hanya didapat dengan mengonsumsi sejumlah makanan.

Ikan dan biota perairan mengandung protein dengan jumlah yang cukup banyak, yaitu $18-20 \%$. Kelebihan yang dimiliki oleh protein biota perairan adalah proteinnya yang mudah dicerna oleh tubuh dan kelengkapan asam amino di dalamnya (Okuzumi dan Fujii 2000).

Kelebihan yang dimiliki oleh protein tidak ditunjang dengan sifatnya yang mudah mengalami perubahan dan kerusakan akibat perlakuan fisik maupun kimia. Perlakuan fisik atau kimia terhadap bahan pangan khususnya biota perairan semenjak penanganan awal, pengolahan, penyimpanan dan akhirnya sampai pada konsumen kerap menyebabkan terjadinya kerusakan nilai gizi, khususnya protein.

Pengolahan yang biasa dilakukan oleh masyarakat adalah menggunakan suhu tinggi, juga akan menyebabkan perubahan kandungan gizi dalam bahan. Penggunaan suhu tinggi dapat memberikan efek positif pada sifat protein, namun bila pemanasan yang dilakukan tidak terkontrol maka dapat menimbulkan berkurangnya nilai protein serta asam amino yang terkandung dalam bahan pangan tersebut.

Fasciolaria salmo atau biasa dikenal oleh masyarakat setempat dengan nama keong ipongipong merupakan salah satu hasil perairan yang mempunyai nilai gizi tinggi dan selalu dikonsumsi oleh masyarakat Gebang Mekar, Cirebon, Jawa Barat. Keong ini sudah biasa dikonsumsi oleh masyarakat karena dipercaya dapat meningkatkan stamina tubuh. Dalam rangka membuktikan kepercayaan masyarakat secara ilmiah tentang manfaat dari keong tersebut, maka perlu dilakukan penelitian tentang kandungan gizi khususnya protein dan taurin dari keong ipong-ipong.

Tujuan penelitian ini adalah menentukan rendemen keong ipong-ipong, kandungan kimia (lemak, protein, dan abu), abu tak larut asam; menentukan asam amino dan taurin dari daging keong segar dan setelah pengolahan dengan cara pengolahan terpilih.

\section{METODE}

\section{Tempat Penelitian}

Penelitian ini dilaksanakan di Laboratorium Karakteristik Bahan Baku Hasil Perairan, Departemen Teknologi Hasil Perairan, Fakultas Perikanan dan Ilmu Kelautan, Laboratorium Biokomia Hasil Perairan, Departemen Teknologi Hasil Perairan, Fakultas Perikanan dan Ilmu Kelautan, Laboratorium Terpadu IPB Baranangsiang.

\section{Bahan dan Alat}

Bahan utama yang digunakan dalam penelitian ini adalah keong ipong-ipong (Fasciolaria salmo). Bahan-bahan kimia yang digunakan dalam analisis antara lain air, akuades, $\mathrm{H}_{2} \mathrm{SO}_{4}, \mathrm{NaOH}, \mathrm{HCl}$, tablet kjeltec, $\mathrm{H}_{3} \mathrm{BO}_{3}$, kertas saring, methanol, merkaptoetanol, brij, pereaksi carrez 1 , pereaksi carrez 2, buffer natrium klorida, larutan dansil klorida, metilamin hidroklorida, dan buffer borat.

Alat yang digunakan dalam penelitian ini adalah termometer, timbangan digital, cawan porselen, oven, desikator, tabung reaksi, labu takar, gelas erlenmenyer, tabung kjeldahl, buret, tabung sokhlet, pemanas, tanur, rotary evaporator, syringe, dan High Performance Liquid Chromatrografy (HPLC).

\section{Tahapan Penelitian}

Penelitian ini dilakukan dalam dua bagian. Bagian pertama meliputi pengambilan sampel, identifikasi, preparasi, penentuan ukuran dan bobot, perhitungan rendemen tubuh, pengolahan, dan uji organoleptik. Bagian kedua berupa perlakuan pengolahan, terdiri dari perebusan $\left(100^{\circ} \mathrm{C}\right.$ selama 15 menit), pengukusan $\left(100^{\circ} \mathrm{C}\right.$ selama 20 menit), dan perebusan dengan penambahan 3\% garam selama 15 menit.

Analisis yang dilakukan meliputi kandungan kimia (AOAC 2005), abu tak larut asam (SNI 2354.1:2010), asam amino (AOAC modifikasi ULFC Shimadzu), dan taurin (AOAC 2005 modifikasi). Data-data yang diperoleh diolah menggunakan ANOVA (sidik ragam) Rancangan Acak Lengkap dengan $a=5 \%$. Bila hasil analisis menunjukkan perlakuan berpengaruh nyata terhadap parameter yang diukur, maka dilakukan uji lanjut Duncan.

\section{HASIL DAN PEMBAHASAN}

\section{Rendemen Keong Ipong-ipong (Fasciolaria salmo)}

Rendemen daging keong ipong-ipong adalah $28.00 \%$, sedangkan rendemen cangkangnya adalah $62.00 \%$. Keong ipong-ipong memiliki nilai rendemen yang paling tinggi pada cangkang karena seluruh tubuhnya ditutupi oleh cangkang. Perhitungan rendemen dilakukan untuk mengetahui seberapa besar bahan baku yang dapat dimanfaatkan. Bagian yang biasa dimanfaatkan dari jenis gastropoda laut 
adalah daging dan cangkangnya. Rendemen daging keong yang hilang akibat pengukusan adalah $9.17 \%$ dan $6.36 \%$ akibat perebusan dengan penambahan garam $3 \%$. Penyusutan rendemen terjadi karena selama proses pengukusan dan perebusan dengan penambahan garam 3\%, air dari dalam daging keluar. Berbeda dengan pengukusan dan perebusan dengan penambahan garam 3\%, keong ipong-ipong mengalami peningkatan rendemen sebesar $2.67 \%$ akibat perebusan. Peningkatan rendemen ini disebabkan air sebagai media perebusan masuk ke dalam daging dan menambah berat keong.

\section{Kandungan Zat Gizi dan Abu tak Larut Asam Keong Ipong-ipong}

Setiap komoditas dan produk pangan memiliki sifat gizi masing-masing. Sifat gizi tersebut dapat diketahui melalui analisis kimia dengan tujuan untuk mengetahui kandungan gizi secara kasar (crude). Pada penelitian ini dilakukan analisis kimia meliputi kadar air, kadar abu, protein, lemak, dan kadar abu tak larut asam. Hasil analisis kimia dan abu tak larut asam daging keong ipong-ipong segar dan setelah pengolahan dapat dilihat pada Tabel 1 .

Hasil analisis ragam menunjukkan bahwa metode pengolahan memberikan pengaruh terhadap kadar air keong ipong-ipong. Daging keong kukus dan rebus dengan penambahan garam 3\% memiliki kadar air yang berbeda dengan daging keong segar dan daging keong rebus. Perebusan dalam larutan garam pada suhu $100^{\circ} \mathrm{C}$ akan menyebabkan penetrasi garam lebih cepat dan pembebasan air dari jaringan sel akan lebih banyak dibandingkan pada suhu normal. Hasil penelitian Kalachova et al. (2006) menunjukkan dua spesies ikan yang ditelitinya memiliki kadar air yang tidak berbeda dengan sampel segar, tetapi mengalami peningkatan setelah perebusan pada suhu $85-90^{\circ} \mathrm{C}$ selama $10-15$ menit. Menurut Prabandari et al. (2005), waktu dan suhu pengolahan dapat memengaruhi nilai kadar air suatu bahan pangan, semakin lama waktu pengolahan dan semakin tinggi suhu yang digunakan akan mengakibatkan banyak air dalam bahan pangan keluar.

Hasil penelitian menunjukkan bahwa metode pengolahan memberikan pengaruh yang nyata pada kandungan kadar abu. Daging keong rebus garam memiliki kadar abu yang berbeda nyata dengan daging keong segar, rebus, dan kukus. Perbedaan kadar abu disebabkan oleh penambahan garam pada air yang digunakan sebagai media perebusan. Daging keong kukus dan daging keong rebus memiliki kadar abu yang tidak berbeda nyata dengan daging keong segar. Penelitian Mubarak (2004) memperlihatkan mineral K dan Fe pada kacang hijau baru mengalami penurunan sebesar $24 \%$ dan $8 \%$ setelah direbus pada suhu $100^{\circ} \mathrm{C}$ selama 90 menit.

Protein merupakan zat gizi yang amat penting bagi tubuh karena disamping berfungsi sebagai bahan bakar dalam tubuh juga berfungsi sebagai zat pengatur dan pembangun. Protein adalah sumber asam-asam amino yang mengandung unsur $\mathrm{C}, \mathrm{H}, \mathrm{O}$, dan $\mathrm{N}$ yang tidak dimiliki oleh lemak atau karbohidrat. Molekul protein juga mengandung fosfor, belerang, dan ada jenis protein yang mengandung unsur logam seperti besi dan tembaga (Winarno 2008).

Hasil analisis ragam menunjukkan metode pengolahan memberikan pengaruh terhadap protein keong ipong-ipong. Hasil uji Duncan memperlihatkan daging keong kukus, rebus, dan rebus dengan penambahan garam 3\% memiliki kadar protein yang berbeda dengan daging keong segar. Perbedaan ini dikarenakan penggunaan suhu tinggi sebagai metode pengolahan. Menurut Selcuk et al. (2010), kadar protein ikan baik dalam basis basah maupun basis kering dapat berubah tergantung kepada jenis spesies dan metode pengolahannya.

Pengolahan menggunakan suhu tinggi mengakibatkan jumlah air bebas hilang dan terjadinya koagulasi sehingga tekstur daging semakin memadat, sejalan dengan itu protein akan mengalami denaturasi sehingga membentuk struktur yang lebih sederhana, hal ini merupakan proses yang umum terjadi akibat pengaruh suhu selama proses pengolahan dan akhirnya dapat menyebabkan berkurangnya kadar protein yang dikandung dalam suatu bahan. Semakin tinggi suhu maka protein akan terhidrolisis dan terdenaturasi, kehilangan aktivitas enzim, terjadi peningkatan kandungan senyawa terekstrak bernitrogen, amonia, dan hidrogen sulfida dalam daging. Menurut Erkan dan Ozden (2011), panas menyebabkan sebagian protein larut dan ikut hilang bersama-sama dengan air yang keluar dari daging. Contoh protein yang larut dalam air antara lain protamin, histon, pepton, proteosa, dan lain-lain.

Hasil analisis ragam pada tingkat kepercayaan 95\% menunjukkan metode pengolahan memberikan pengaruh terhadap kandungan lemak keong ipong-i-

Tabel 1. Kandungan Gizi dan Abu Tak Larut Asam Keong Ipong-ipong

\begin{tabular}{lcccc}
\hline \multicolumn{1}{c}{ Jenis Gizi } & Keong Segar & Keong Kukus & Keong Rebus & Keong Rebus+Garam \\
\hline Air (\%bb) & $258.87 \mathrm{a}$ & $214.42 \mathrm{~b}$ & $266.15 \mathrm{a}$ & $222.22 \mathrm{~b}$ \\
Abu (\%bk) & $7.80 \mathrm{ab}$ & $6.56 \mathrm{a}$ & $6.78 \mathrm{a}$ & $11.11 \mathrm{c}$ \\
Abu tak larut asam & $0.72 \mathrm{ab}$ & $0.6 \mathrm{a}$ & $0.70 \mathrm{ab}$ & $2.22 \mathrm{c}$ \\
Protein (\%bk) & $62.72 \mathrm{~b}$ & $49.25 \mathrm{a}$ & $45.66 \mathrm{a}$ & $44.05 \mathrm{a}$ \\
Lemak (\%bk) & $1.71 \mathrm{~d}$ & $1.26 \mathrm{c}$ & $0.1 \mathrm{ab}$ & $0.76 \mathrm{a}$ \\
\hline Keterangan: bb=basis & & &
\end{tabular}


pong. Hasil uji lanjut Duncan memperlihatkan daging keong rebus dan rebus dengan penambahan garam $3 \%$, serta kukus memiliki kadar lemak yang berbeda dengan daging keong segar. Hal ini disebabkan suhu yang digunakan untuk perebusan adalah $100^{\circ} \mathrm{C}$ sehingga lemak mencair dan larut bersama dengan air pada media perebusan. Menurut Tapotubun et al. (2008), suhu dan waktu pemanasan memberikan efek pada kadar lemak produk, hal ini erat kaitannya dengan sifat lemak tersebut yang berbentuk padat pada suhu kamar sedangkan suhu yang dicapai pada perebusan adalah $100^{\circ} \mathrm{C}$ sehingga lemak akan mencair dan hilang bersama-sama dengan air. Lemak merupakan sumber energi yang lebih efektif dibandingkan dengan karbohidrat dan protein.

Pengaruh pemanasan selama proses perebusan akan memecah komponen-komponen lemak menjadi produk volatil seperti aldehid, keton, alkohol, asam, dan hidrokarbon yang sangat berpengaruh terhadap pembentukan flavor.

Hasil analisis ragam pada tingkat kepercayaan 95\% menunjukkan metode pengolahan memberikan pengaruh terhadap kadar abu tak larut asam keong ipong-ipong. Hasil uji lanjut Duncan menunjukkan kadar abu tak larut asam daging keong segar, rebus, kukus, berbeda terhadap daging keong rebus dengan penambahan garam $3 \%$. Perbedaan ini dikarenakan adanya penambahan garam pada air perebusan. Kadar abu tak larut asam yang ada pada keong ipong-ipong juga dapat berasal dari material-material yang terdapat di perairan tempat keong ipongipong hidup seperti pasir, lumpur, batu, dan silika. Material tak larut asam ini ikut masuk ke dalam saluran pencernaan keong ipong-ipong ketika sedang melakukan aktivitas makan, kemudian mengendap di dalamnya. Menurut Nurjanah (2009), lintah laut (Discodoris sp.) yang termasuk golongan gastropoda memiliki kadar abu tak larut asam yang lebih tinggi jika dibandingkan dengan lintah laut yang dibuang jeroannya. Menurut Basmal et al. (2003), kadar abu tak larut asam merupakan salah satu kriteria dalam menentukan tingkat kebersihan dalam proses pengolahan.

\section{Komposisi Asam Amino Keong Ipong-ipong}

Mutu protein ditentukan oleh jenis dan proporsi asam amino yang dikandungnya. Protein yang bermutu tinggi adalah protein yang mengandung semua jenis asam amino esensial dalam proporsi yang sesuai untuk pertumbuhan. Semua protein hewani, kecuali gelatin merupakan protein yang bermutu tinggi.

Analisis asam amino dilakukan untuk menduga komposisi asam amino dan menentukan kadar asam amino pada protein keong ipong-ipong dalam keadaan segar dan setelah pengolahan. Asam amino dibagi menjadi dua, yaitu asam amino non esensial dan asam amino esensial. Kandungan asam amino daging keong ipong-ipong segar dan setelah pengolahan dapat dilihat pada Tabel 2.

Metode analisis HPLC yang digunakan adalah hidrolisat asam, sehingga hanya dapat menganalisis 15 jenis asam amino yang terdiri dari sembilan jenis asam amino esensial dan enam asam amino non esensial. Menurut Selcuk et al. (2010), asam amino esensial untuk orang dewasa terdiri dari lisin, leusin, isoleusin, treonin, metionin, valin, fenilalanin, dan triptofan, sedangkan asam amino esensial

Tabel 2. Kandungan Asam Amino Keong Ipong-ipong Segar dan Setelah Pengolahan

\begin{tabular}{lcccc}
\hline \multirow{2}{*}{ Asam Amino } & \multicolumn{4}{c}{ Hasil (\% g Asam Amino/100 g Sampel) (bb) } \\
\cline { 2 - 5 } & Keong Segar & Keong Kukus & Keong Rebus & Keong Rebus+Garam \\
\hline Aspartat & 1.34 & 1.29 & 1.02 & 1.26 \\
Glutamat & 2.24 & 2.16 & 1.67 & 2.10 \\
Serin & 0.73 & 0.64 & 0.63 & 0.53 \\
Histidin* & 0.27 & 0.23 & 0.22 & 0.20 \\
Glisin & 0.73 & 0.54 & 0.62 & 0.50 \\
Treonin* & 0.60 & 0.53 & 0.48 & 0.46 \\
Arginin* & 1.27 & 1.25 & 1.22 & 1.03 \\
Alanin & 1.37 & 1.19 & 1.03 & 0.98 \\
Tirosin & 0.53 & 0.45 & 0.42 & 0.40 \\
Metionin* & 0.42 & 0.36 & 0.32 & 0.34 \\
Valin* & 0.65 & 0.57 & 0.52 & 0.48 \\
Fenilalanin* & 0.55 & 0.43 & 0.40 & 0.42 \\
Isoleusin* & 0.56 & 0.48 & 0.41 & 0.44 \\
Leusin* & 1.24 & 1.14 & 0.97 & 0.97 \\
Lisin* & 1.27 & 1.03 & 0.78 & 1.11 \\
Total & 13.77 & 12.27 & 10.71 & 11.23 \\
* Asam amino esensial & & & &
\end{tabular}


bagi anak-anak ditambah arginin dan histidin. Asam amino non esensial terdiri dari asam aspartat, asam glutamat, alanin, asparigin, sistein, glisin, prolin, tirosin, serin, dan glutamin.

Kandungan asam amino esensial yang tertinggi pada daging keong segar adalah arginin. Arginin adalah asam amino yang dibentuk di hati dan beberapa diantaranya dalam ginjal. Menurut Emmanuel et al. (2008), arginin sangat penting bagi anak-anak. Arginin juga bermanfaat untuk meningkatkan pengeluaran hormon pertumbuhan dan meningkatkan kesuburan pria. Kandungan arginin pada daging keong segar adalah 1.27\%. Selain arginin, asam amino esensial lainnya yang tinggi pada daging keong segar adalah lisin. Kandungan lisin pada daging keong segar sama dengan kandungan arginin yaitu $1.27 \%$.

Lisin berfungsi sebagai bahan dasar antibodi darah, memperkuat sistem sirkulasi, mempertahankan pertumbuhan sel-sel normal, bersama prolin dan vitamin C akan membentuk kolagen dan menurunkan kadar trigliserida darah yang berlebihan. Kekurangan lisin dapat menyebabkan mudah lelah, sulit konsentrasi, rambut rontok, anemia, pertumbuhan terhambat, dan kelainan reproduksi (Harli 2008). Menurut Rosa dan Nunes (2004) asam amino arginin, lisin, dan leusin adalah asam amino esensial yang penting dari hewan perairan, oleh karena itu dikenal sebagai pangan tinggi protein.

Kandungan asam amino non esensial yang tertinggi pada daging keong segar dan setelah pengolahan adalah asam glutamat dan asam aspartat. Menurut Oladapa et al. (1984), asam glutamat dan asam aspartat penting karena menciptakan karakteristik aroma dan rasa pada makanan.

Asam glutamat dapat diproduksi sendiri oleh tubuh manusia. Pada asam glutamat terdapat ion glutamat yang dapat merangsang beberapa tipe saraf yang ada pada lidah manusia. Sifat ini dapat dimanfaatkan oleh industri penyedap karena garam turunan dari asam glutamat (monosodium glutamat) sangat dikenal sebagai penyedap masakan.

Asam amino daging keong ipong-ipong baik esensial maupun non esensial mengalami penurunan akibat pengolahan. Jumlah kandungan asam amino pada daging keong segar adalah $13.77 \%$. Pengukusan menyebabkan penurunan asam amino sebesar $10.89 \%$, perebusan dengan penambahan garam $3 \%$ sebesar $18.45 \%$ dan perebusan sebesar $22.22 \%$. Penurunan kandungan asam amino pada daging keong setelah pengolahan disebabkan oleh penggunaan suhu tinggi. Pengolahan daging dengan menggunakan suhu tinggi akan menyebabkan denaturasi protein.

Denaturasi protein adalah berubahnya susunan ruang atau rantai polipeptida suatu molekul protein. Jika ikatan-ikatan yang membentuk konfigurasi molekul tersebut rusak, molekul akan mengembang.
Kadang perubahan seperti ini memang dikehendaki, namun sering pula dianggap merugikan.

Penurunan kandungan asam amino pada daging keong kukus lebih kecil dibandingkan dengan metode pengolahan lainnya. Hal ini didukung dengan rendahnya kadar air daging keong yang di kukus. Penurunan kadar air karena proses pengukusan akan menyebabkan protein lebih terkonsentrasi. Menurut Tapotubun et al. (2008), keluarnya air dari bahan pangan menyebabkan protein lebih terkonsentrasi dibandingkan dengan yang lain sehingga kandungan asam aminonya lebih baik dibandingkan dengan metode pengolahan lain.

Secara umum pengaruh pengolahan menggunakan panas dapat mengakibatkan penyusutan jumlah asam amino tergantung dari jenis pengolahan, suhu, dan lamanya proses pengolahan. Menurut Ekop (2008), penurunan asam amino lebih dari 10\% akan memberikan pengaruh yang signifikan terhadap mutu bahan pangan tersebut.

Asam amino terendah pada daging keong baik segar maupun setelah proses pemasakan adalah histidin. Kandungan histidin pada daging keong segar adalah $0.27 \%$, keong rebus adalah $0.22 \%$, keong rebus garam adalah $0.20 \%$, dan keong kukus adalah $0.23 \%$. Menurut Selcuk et al. (2010), histidin berfungsi dalam pertumbuhan dan perbaikan jaringan tubuh serta memproduksi sel darah merah.

\section{Kandungan Taurin Keong Ipong-ipong}

Taurin adalah asam amino non esensial yang mengandung sulfur, tetapi tidak termasuk kelompok protein karena tidak memiliki gugus karboksil $(-\mathrm{COOH})$ yang diperlukan untuk membentuk ikatan peptida. Taurin dapat ditemukan dalam berbagai sumber makanan seperti daging dan ikan (Santoso 2011).

Kandungan taurin pada daging keong segar adalah $164.17 \mathrm{mg} / 100 \mathrm{~g}$ dan pada daging keong kukus (metode pengolahan terbaik) adalah 149.62 $\mathrm{mg} / 100 \mathrm{~g}$. Penurunan kandungan taurin ini disebabkan oleh pengukusan menggunakan suhu tinggi selama periode waktu tertentu menimbulkan adanya uap air yang dapat melarutkan taurin di dalam bahan pangan. Menurut Dragnes et al. (2009), taurin merupakan jenis asam amino yang larut dalam air. Pemasakan dengan suhu tinggi menyebabkan taurin terlepas dari bahan pangan kemudian larut dalam air dan ikut keluar terbawa oleh uap air sehingga kandungannya berkurang.

Kandungan taurin daging keong segar dan kukus masih lebih rendah bila dibandingkan dengan oyster (1 178 mg/100 g), gurita (871 mg/100 g), scallop (669 mg/100 g), dan cumi-cumi jepang (364 mg/100 g), namun lebih tinggi bila dibandingkan dengan hati sapi (45 mg/100 g), daging sapi (48 mg/100 g), dan cakalang (3 mg/100 g) (Okuzumi \& Fujii 2000). 


\section{KESIMPULAN}

Keong ipong-ipong (Fasciolaria salmo) memiliki rendemen cangkang $62.00 \%$ dan daging $28.00 \%$. Kandungan asam amino pada daging keong segar adalah $13.77 \%$ dan mengalami penurunan setelah pengolahan. Pengukusan menyebabkan penurunan asam amino sebesar $10.89 \%$, perebusan dengan penambahan garam $3 \%$ sebesar $18.45 \%$ dan perebusan sebesar 22.22\%. Kandungan asam amino esensial tertinggi pada keong ipong-ipong adalah arginin dan asam amino non esensial tertinggi adalah asam glutamat. Pengukusan memiliki kandungan asam amino terbaik, sehingga daging keong kukus dilanjutkan untuk analisis kandungan taurin. Kandungan taurin daging keong segar mengalami penurunan akibat pengukusan dari $164.17 \mathrm{mg} / 100 \mathrm{~g}$ menjadi $149.62 \mathrm{mg} / 100 \mathrm{~g}$.

\section{DAFTAR PUSTAKA}

[AOAC] Associaton of Official Analytical Chemist. 2005. Official Method of Analysis of The Association of Official Analitycal of Chemist. The Association of Official Analitycal Chemist, Inc, Arlington, Virginia, USA.

Basmal J, Syarifudin, \& Farid MW. 2003. Pengaruh konsentrasi larutan potassium hidroksida terhadap mutu kappa-karaginan yang diekstraksi dari Eucheuma cottonii. Jurnal Penelitian Perikanan Indonesia, 9(5), 95-104.

Dragnes BT, Larsen R, Emhsen MH, \& Elvevoli EO. 2009. Impact of processing on the taurine content in processed seafood and their corresponding unprocessed raw materials. J Sci Food Agric, 60(2), 143-152.

Ekop AS. 2008. Changes in amino acid composition of African yam beans (Sphenostylis stenocarpas) and African locust beans (Parkia filicoida) on cooking. Pakistan Journal of Nutrition, 5(3), 254-256.

Emmanuel I, Adeyeye, Amoke M, \& Kenni. 2008. The relationship in the amino acid of the whole body, flesh and exoskeleton of common west African fresh water male crab Sudananautes africanus. Pakistan Journal of Nutrition, 7(6), 748-752.

Erkan N \& Ozden O. 2011. A preliminary study of amino acid and mineral profiles of important and estimable 21 seafood species. British Food Journal, 4(113), 457-569.

Harli M. 2008. Asam amino esensial. http://www.supamas.com [15 April 2011].

Ikram EHK \& Ismail A. 2004. Effects of cooking prac- tices (boiling and frying) on the protein and amino acids contents of four selected fishes. J Sci Food Nut, 34(2), 54-59.

Kalachova GS, Demirchieva SM, Gubanenko GA, Sushcik NN, \& Gladyshev MI. 2006. Effect of boiling and frying on the content of essential polyunsaturated fatty acids in muscle tissue of four fish species. J Chem Food, 101(2007), 1694-1700.

Mubarak AE. 2004. Nutritional composition and antinutritional factors of mung bean seeds (Phaseolus aureus) as affected by some home traditional processes. J Chem Food, 89, (2005), 489-495.

Nurjanah. 2009. Karakterisasi lintah laut (Discodoris sp.) dari perairan pantai Pulau Buton sebagai antioksidan dan antikolesterol [disertasi]. Sekolah Pascasarjana, Institut Pertanian Bogor, Bogor.

Okuzumi M \& Fujii T. 2000. Nutritional and Functional Properties of Squid and Cuttlefish. Tokyo University of Fisheries, Japan.

Oladapa A, Akin MAS, \& Olusegun LO. 1984. Quality changes of Nigerian traditionally processed freshwater fish species. J Food Tech, 19(1984), 341-348.

Prabandari R, Mangalik A, Achmad J, \& Agustiana. 2005. Pengaruh waktu perebusan dari dua jenis udang yang berbeda terhadap kualitas tepung limbah udang putih (Penaeus indicus) dan udang windu (Penaeus monodon). Enviroscienteae, 1(1), 24-28.

Rosa R \& Nunes ML. 2004. Nutritional quality of red shrimp (Aristeus antennatus), pink shrimp (Parapenaeus longirostris), and Norway lobster (Nephrops norvegicus). J Sci Food Agric, 94(2004), 84-89.

Santoso D. 2011. Taurin untuk performa mental dan atletik yang optimal. http://www.dennysantoso.com [15 April 2011].

Selcuk A, Ozden O, \& Erkan N. 2010. Effect of frying, grilling, and steaming on amino acid composition of marine fishes. J Med Food, 13(6), 1524-1531.

[SNI] Standar Nasional Indonesia. 2010. Cara Uji Kimia-Bagian 1: Penentuan Kadar Abu dan Abu Tak Larut Asam pada Produk Perikanan. Standar Nasional Indonesia, Jakarta.

Tapotubun AM, Nanlohy E, \& Louhenapessy J. 2008. Efek waktu pemanasan terhadap mutu presto beberapa jenis ikan. Ichthyos, 7(2), 65-70.

Winarno FG. 2008. Kimia Pangan dan Gizi. PT Gramedia, Jakarta. 